\title{
Quality characteristics and antioxidant activities of rice cookies added with Lentinus edodes powder
}

\author{
Mee-Jin Kim, Hai-Jung Chung* \\ Department of Food Science and Nutrition, Daejin University, Pocheon 11159, Korea
}

\section{표고버섯 분말을 첨가한 쌀 쿠키의 품질 특성 및 항산화 활성}

\author{
김미진 · 정해정* \\ 대진대학교 식품영양학과
}

\begin{abstract}
This study was conducted to investigate the effect of Lentinus edodes powder on the quality characteristics and antioxidant of rice cookies. The cookies for this experiment was made by 3 main ingredients including rice powder, flour, Lentinus edodes powder. The proportion of rice powder was fixed to $50 \%$ for the total amount of ingredients. The amount of reminded 2 ingredients (flour and Lentinus edodes powder) were varied. The amount of flour was decreased up to $38 \%$, and the addition of Lentinus edodes powder was increased to $4 \%, 8 \%$ and $12 \%$. Density of the dough, hardness, total polyphenol content, DPPH free radical scavenging activity, and reducing power increased with increasing Lentinus edodes powder content. Moisture content, $\mathrm{pH}$ of the dough, spread factor, loss rate, leavening rate, and $L$ values of the cookies were decreased with increasing Lentinus edodes powder content. The result of consumer acceptance test revealed that there were no significant differences in smell, taste and overall acceptability, while the preference of color decreased as the amount of Lentinus edodes powder increased. To sum up, the cookies with $12 \%$ Lentinus edodes powder can produced the best results in terms of quality and antioxidant potential.
\end{abstract}

Key words : Lentinus edodes, cookies, hardness, antioxidant activity

\section{서 론}

표고버섯(Lentinus edodes)은 담자균아문 주름버섯목에 속하는 버섯으로 중국에서 $\mathrm{AD} 1,000$ 년경에 재배가 시작된 것으로 알려져 있으며, 우리나라에서는 1930년대부터 재배 하기 시작하였다(1). 표고버섯은 풍미가 뛰어나고 탄수화 물, 단백질, 지질을 비롯하여 $\mathrm{Ca}, \mathrm{P}, \mathrm{Fe}, \mathrm{K}$ 등의 무기질과 비타민 $\mathrm{B}_{1}, \mathrm{~B}_{2}$ 및 나이아신 등을 다량 함유하고 있으며, 고혈압, 위궤양, 신장염, 신경쇠약, 불면증, 빈혈, 혈청지질 농도 개선, 항치매, 뇌졸중, 심장질환 등의 질환 예방에 효과 가 있는 것으로 밝혀져서 식용뿐만 아니라 건강증진식품으

*Corresponding author. E-mail : haijung@daejin.ac.kr

Phone : 82-31-539-1861, Fax : 82-31-539-1860

Received 20 March 2017; Revised 15 May 2017; Accepted 25 May 2017.

Copyright (c) The Korean Society of Food Preservation. All rights reserved.
로 크게 각광을 받고 있다 $(1,2)$. 표고버섯의 자실체에 함유 되어 있는 $\beta$-glucan은 손상된 면역기능을 회복시켜 주거나 촉진시켜 줌으로써 항암 효과를 나타내며, 혈중 포도당 농 도를 감소시켜 당뇨병 개선 효과가 있다고 보고되고 있다 $(2,3)$.

우리 식생활의 서구화로 인하여 쌀의 소비는 급속히 감 소한 반면, 면류, 빵류, 과자류와 같은 밀 가공제품 소비량은 계속 증가하고 있으나 쌀 생산량은 크게 줄지 않고 있으므 로 국내 쌀 소비를 촉진하는 전략이 절실히 요구되고 있다 (4). 쌀 소비의 대부분은 주식인 밥 형태로 소비되고 있으며 전체 생산량의 2\%-3\%만이 떡이나 주류, 한과 등과 같은 가공식품 형태로 소비되고 있으므로(4), 쌀 소비를 늘리기 위해서는 밀가루를 쌀로 대체할 수 있는 다양한 제품 개발 이 필요하다. 쌀은 다른 곡류에 비해 전분 입자의 크기가 작아 제과제빵 분야에서 밀가루를 대체할 수 있는 좋은 소재이나 쌀에는 밀가루 반죽 과정에서 형성되는 점탄성 단백질인 글루텐이 존재하지 않아 밀가루 일부를 쌀로 대체 
하거나 글루텐을 첨가한 쌀 제품 등은 제빵성이 떨어진다고 보고된 바 있다(4-6).

제과의 한 종류인 쿠키는 고소하고 바삭한 식감이 좋아 커피, 차, 음료에 곁들여 먹기 좋고 수분 함량이 낮아 저장성 이 우수하여 쿠키에 다양한 생리활성 성분을 함유하고 있는 소재를 첨가하여 기능성이 추가된 쿠키 제조 연구가 활발히 진행되고 있다(7). 선행 연구로는 현미 분말(4,5), 음나무잎 분말(6), 울금 분말(7), 기능성 쌀가루(8), 흑미 가루(9), 양송 이버섯 분말(10), 새송이버섯 분말(11) 검은비늘버섯 분말 (12), 구아바 분말(13), 자색고구마 분말(14), 솔잎 분말(15), 더덕 분말(16), 흑임자 분말(17), 미역 분말(18), 당근 분말 (19), 타피오카 전분(20) 등이 첨가된 쿠키에 관한 연구가 보고되어 있다. 이에 본 연구에서는 건강 지향적인 기능성 제과 개발을 위한 시도로써 다양한 생리활성을 지닌 표고버 섯 분말을 첨가하여 쿠키를 제조한 후 이화학적 특성과 항산화 효과를 측정하여 현대인의 기호에 맞는 건강식품으 로의 쿠키 개발 가능성을 조사하였다.

\section{재료 및 방법}

\section{실험재료}

본 실험에서 사용한 박력밀가루(CJ, Yangsan, Korea), 박 력쌀가루(Daedoo Foods, Gunsan, Korea), 버터(Seoulmilk, Seoul, Korea), 백설탕(CJ, Incheon, Korea), 달걀, 베이킹파 우더(Ruf, Lebensmittelwerk, Quakenbruck, Germany)는 시 판되는 것을 구입하였다. 표고버섯 분말은 경기도 포천의 대형 마트에서 표고버섯을 구입하여 조직을 파쇄한 후 -7 $0{ }^{\circ} \mathrm{C}$ 에서 동결시킨 다음 동결건조기(TFD, Ilshin, Seoul, Korea)를 이용하여 건조하였다. 건조된 시료는 분쇄하여 60 mesh 체로 친 다음 $-20^{\circ} \mathrm{C}$ 에 냉동 보관하며 사용하였다.

쌀 쿠키 제조

표고버섯 분말 첨가 쌀 쿠키의 배합비는 Table 1 과 같다.

Table 1. Formula for rice cookies added with Lentinus edodes powder

\begin{tabular}{lcccc}
\hline \multirow{2}{*}{ Ingredients (g) } & \multicolumn{4}{c}{ Group $^{1)}$} \\
\cline { 2 - 5 } & C-0 & C-4 & C-8 & C-12 \\
\hline Rice powder & 50 & 50 & 50 & 50 \\
Flour & 50 & 46 & 42 & 38 \\
Lentinus edodes powder & 0 & 4 & 8 & 12 \\
Butter & 60 & 60 & 60 & 60 \\
Sugar & 40 & 40 & 40 & 40 \\
Egg & 20 & 20 & 20 & 20 \\
Baking powder & 1 & 1 & 1 & 1 \\
\hline
\end{tabular}

${ }^{1)} \mathrm{C}-0$, Lentinus edodes powder-0\%; C-4, Lentinus edodes powder-4\%; C-8, Lentinus edodes powder-8\%; C-12, Lentinus edodes powder- $12 \%$.
박력밀가루, 박력쌀가루, 표고버섯 분말, 베이킹파우더를 체질하여 두고, 중탕한 버터, 설탕, 계란을 2 분간 크림화 한 다음 체질해 둔 재료들을 넣고 다시 30초간 혼합하였다. 이것을 한 덩어리로 뭉쳐 랩으로 싸서 냉장온도 $\left(4 \pm 2^{\circ} \mathrm{C}\right)$ 에 서 1시간 숙성시킨 다음 두께 $5 \mathrm{~mm}$, 직경 $50 \mathrm{~mm}$ 의 쿠키 모양으로 성형하여 예열된 오븐(FDO-7102, Daeyoung, Seoul, Korea)에 넣고 윗불 $190^{\circ} \mathrm{C}$, 아랫불 $150^{\circ} \mathrm{C}$ 에서 12 분간 구운 후 꺼내어 실온에서 2 시간 냉각하고 분석실험의 시료 로 사용하였다.

\section{쌀 쿠키 반죽의 밀도 및 $\mathrm{pH}$ 측정}

쌀 쿠키 반죽의 밀도(density)는 $50 \mathrm{~mL}$ 의 메스실린더에 증류수 $30 \mathrm{~mL}$ 를 넣고 쿠키반죽 $5 \mathrm{~g}$ 을 넣었을 때 증가한 부피를 구하여 무게의 비 $(\mathrm{g} / \mathrm{mL})$ 로 구하였다. $\mathrm{pH}$ 는 증류수 $40 \mathrm{~mL}$ 와 반죽 $4 \mathrm{~g}$ 을 교반시킨 후 $\mathrm{pH}$ meter(InoLab pH 720, WTW, Weilheim, Germany)로 측정하였다.

$$
\text { 밀도 }(\mathrm{g} / \mathrm{mL})=\frac{\text { 반죽의 무게 }(\mathrm{g})}{\text { 반죽의 부피 }(\mathrm{mL})}
$$

\section{쌀 쿠키의 퍼짐성, 손실률 및 팽창률 측정}

쌀 쿠키의 퍼짐성 지수(spread factor)는 AACC법(21)에 준하여 쿠키 직경에 대한 높이의 비로 나타내었다. 쿠키의 직경은 6 개를 가로로 정렬하여 그 길이를 측정한 후 각각의 쿠키를 $90^{\circ}$ 로 회전시킨 후 동일한 방법으로 총 길이를 측정 하고 6 으로 나누어 쿠키 한 개에 대한 평균 직경을 구하였 다. 쿠키의 평균 높이는 쿠키 6개를 수직으로 쌓아 올려 그 높이를 측정하고 다시 쿠키의 쌓은 순서를 바꾼 후 높이 를 측정하는 방식으로 측정하였다. 손실률(loss rate)과 팽창 률(leavening rate)은 대조군 및 첨가군의 굽기 전후의 중량 을 각각 측정하여 그 차이에 대한 비율로 다음의 식에 따라 산출하였다.

퍼짐성 지수 $=\frac{\text { 쿠키 } 1 \text { 개의 평균 직경 }(\mathrm{mm})}{\text { 쿠키 } 1 \text { 개의 평균 높이 }(\mathrm{mm})}$

$$
\text { 손실률 }(\%)=\frac{\text { 굽기 전후 } 1 \text { 개의 중량차 }(\mathrm{g})}{\text { 굽기 전 반죽 } 1 \text { 개의 중량 }(\mathrm{g})} \times 100
$$

팽창률 $(\%)=\frac{\text { 첨가군 쿠키의 굽기 전후의 중량차 }(\mathrm{g})}{\text { 대조군 쿠키의 굽기 전후의 중량차 }(\mathrm{g})} \times 100$

\section{쌀 쿠키의 색도 측정}

쌀 쿠키의 색도는 색차계(JX 777, Juki, Tokyo, Japan)를 사용하여 명도(L, lightness), 적색도(a, redness), 황색도(b, yellowness) 값을 측정하였고 색차 측정에 의해 $\Delta \mathrm{E}$ (색도차; color difference)값을 얻었다. 이때 사용한 표준백판은 $\mathrm{L}=97.67, \mathrm{a}=0.46, \mathrm{~b}=-0.64$ 였다. 
$\Delta \mathrm{E}=\Delta \quad \Delta a^{2}+\Delta b^{2}$

쌀 쿠키의 경도 측정

쌀 쿠키의 경도는 rheometer(Compac-100, Sun Scientific Co., Tokyo, Japan)를 사용하여 쿠키가 중심에서 부서질 때 받는 최대 힘을 각 처리군당 6회 반복 측정하여 평균값을 이용하였다. 측정 시 사용된 조건은 test type: hardness, load cell: $10 \mathrm{~kg}$, distance: $50 \%$, table speed: $120 \mathrm{~mm} / \mathrm{min}$, adaptor type: round(diameter $10 \mathrm{~mm}$ )로 설정하였다.

\section{쌀 쿠키의 미세구조 관찰}

쌀 쿠키의 표면과 내부 조직의 미세구조는 $5.00 \mathrm{kV}$ 가속 전압, 1 torr 상태에서 전계방사형주사전자현미경(Scanning election microscope, Philips, XL30, SFEG, Netherlands)으로 관찰하였다.

\section{쌀 쿠키의 수분 함량 측정}

쌀 쿠키의 수분 함량은 $\mathrm{AOAC}$ 법(22)에 따라 $105^{\circ} \mathrm{C}$ 에서 상압가열건조법으로 측정하였다.

\section{쌀 쿠키의 기호도 조사}

기호도 조사는 냉장 보관된 쿠키를 실온에서 1시간 방치 한 후 사용하였으며 관능검사 요원은 20-50세의 일반인 30 명을 대상으로 본 연구의 목적과 평가항목에 대하여 설 명한 후 실험을 실시하였다. 쿠키는 한 입에 먹기 좋은 크기 로 만들어 임의의 3자리 숫자로 각각 표기하여 흰 접시에 담아 제공하였으며, 평가 항목은 색(color), 냄새(smell), 맛 (taste), 전체적인 기호도(overall acceptability)로 하였고 각 항목에 대하여 7점 척도법(1점, 매우 싫다; 2점, 보통으로 싫다; 3점, 약간 싫다; 4점, 좋지도 싫지도 않다; 5점, 약간 좋다; 6점, 보통으로 좋다; 7점, 매우 좋다)을 사용하여 평가 하였다.

\section{시료액 조제}

쿠키 $10 \mathrm{~g}$ 에 $70 \%$ methanol $20 \mathrm{~mL}$ 를 가하여 실온에서 2시간 진탕 교반한 후 원심분리기(Fleta-5, Hanil Science Co., Inchun, Korea)를 사용하여 $4,000 \mathrm{rpm}$ 에서 10 분간 원심 분리 한 뒤 Whatman No. 1 여과지(GE Healthcare UK Ltd., Little Chalfont, UK)로 여과하여 시료로 사용하였다.

\section{총 폴리페놀 함량 측정}

총 폴리페놀 함량은 Dewanto 등(23)의 방법을 일부 변형 하여 각 시료 용액 $0.1 \mathrm{~mL}$ 에 증류수 $1.9 \mathrm{~mL}$ 와 Folin \& Ciocalteu's phenol reagent(Sigma-Aldrich Co., St. Louis, $\mathrm{MO}, \mathrm{USA}) 0.2 \mathrm{~mL}$ 를 가한 후 실온에서 3 분간 방치하고, 포화 sodium carbonate 용액 $0.4 \mathrm{~mL}$ 를 가하여 혼합한 후 다시 증류수 $1.9 \mathrm{~mL}$ 를 첨가하였다. 이 혼합액을 실온에서
1시간 동안 반응시킨 후 $725 \mathrm{~nm}$ 에서 흡광도(Smart Plus SP-1900PC, Seoul, Korea)를 측정하였다. 표준물질로는 gallic acid를 사용하여 검량선을 작성한 후 시료 $100 \mathrm{~g}$ 중의 gallic acid로 나타내었다.

\section{항산화 활성 측정}

쿠키의 1,1-diphenyl-2-picrylhydrazyl(DPPH) radical 소거 능은 시료용액 $0.1 \mathrm{~mL}$ 에 $99 \%$ methanol로 용해한 $0.1 \mathrm{mM}$ $\mathrm{DPPH}$ 용액 $2 \mathrm{~mL}$ 를 첨가한 후 혼합하고 실온에서 30 분간 반응시킨 다음 $517 \mathrm{~nm}$ 에서의 흡광도를 측정하여 다음 식에 따라 DPPH radical 소거능을 구하였다.

DPPH radical scavenging activity $(\%)=\left(1-\frac{\text { 시료구 흡광도 }}{\text { 대조구 흡광도 }}\right) \times 100$

환원력(reducing power)은 Wong과 Chye(24)의 방법을 변 형하여 측정하였다. 각 시료 용액 $0.4 \mathrm{~mL}$ 에 $0.2 \mathrm{M}$ sodium phosphate buffer( $\mathrm{pH}$ 6.6) $0.5 \mathrm{~mL}$ 와 $1 \%$ potassium ferricyanide $0.5 \mathrm{~mL}$ 를 혼합하여 $50^{\circ} \mathrm{C}$ 에서 20 분간 반응시킨 후 $10 \%$ trichloroacetic acid(TCA) 용액 $0.5 \mathrm{~mL}$ 를 가하여 혼합하여 10 분간 방치하였다. 이를 원심분리하여 얻은 상층액 중 0.5 $\mathrm{mL}$ 를 취하고 증류수 $0.5 \mathrm{~mL}$ 와 $0.1 \% \mathrm{FeCl}_{3} 0.2 \mathrm{~mL}$ 를 가하여 $700 \mathrm{~nm}$ 에서 흡광도를 측정하였다.

\section{통계처리}

모든 실험은 3회 이상 반복 측정하였고 자료의 통계처리 는 Statistical package for social sciences(version 12.0, SPSS Inc., Chicago, IL, USA)를 이용하여 분산분석(ANOVA)을 실 시하였으며, 실험군 간의 유의성은 Duncan의 다중범위검 정(Duncan's multiple range test)으로 $\mathrm{p}<0.05$ 수준에서 비교 하였다.

\section{결과 및 고찰}

쌀 쿠키 반죽의 밀도 및 $\mathrm{pH}$

표고버섯 분말 첨가 쌀 쿠키 반죽의 밀도 및 $\mathrm{pH}$ 를 측정한 결과는 Table 2 와 같다. 반죽의 밀도는 대조군이 $1.11 \mathrm{~g} / \mathrm{mL}$ 로 가장 낮았으며 $4 \%, 8 \%$ 및 $12 \%$ 첨가군이 각각 $1.13 \mathrm{~g} / \mathrm{mL}$, $1.14 \mathrm{~g} / \mathrm{mL}, 1.16 \mathrm{~g} / \mathrm{mL}$ 로 표고버섯 분말 첨가량이 증가함에 따라 증가하였는데, 이는 쿠키 반죽의 휴지과정에서 표고 버섯 분말에 함유되어 있는 섬유소가 밀가루와 쌀가루의 단백질과 상호작용하여 반죽의 밀도를 증가시킨 것으로 사료된다. 밀도는 쿠키의 품질관리에 있어서 중요한 요소 중의 하나로 주재료와 첨가재료의 종류 및 사용량, 반죽의 혼합 방법과 시간, 팽창제의 종류와 사용량, 굽는 온도와 시간 등과 관련이 있는 것으로 알려져 있으며(4), 밀도가 
너무 낮으면 견고성이 높아져서 딱딱해져 기호성이 떨어지 나 너무 높으면 쉽게 부스러진다. 솔잎 분말(15)과 미역 분말(18) 첨가 쿠키의 연구에서도 부재료의 첨가량이 증가 할수록 반죽의 밀도가 증가하였다고 보고하여 본 실험의 결과와 유사한 경향을 보였다.

쌀 쿠키 반죽의 $\mathrm{pH}$ 는 대조군이 6.55 로 가장 높았으며 첨가군은 6.16-6.34로 표고버섯 분말 첨가량이 증가함에 따라 감소하였는데 이는 표고버섯 분말에 함유되어 있는 malic acid, citric acid, lactic acid 등의 유기산이 쿠키 반죽의 $\mathrm{pH}$ 에 영향을 준 것으로 판단된다. Choi 등(25)도 표고버섯 추출물을 첨가한 발효유의 연구에서 발효시간이 경과할수 록 버섯 추출물에 함유된 유기산의 영향에 의하여 버섯 추출물 첨가구의 $\mathrm{pH}$ 가 감소하였다고 보고하였으며 검은비 늘버섯 분말 첨가 쿠키(12)의 연구에서도 부재료의 첨가량 이 증가할수록 $\mathrm{pH}$ 가 감소하였다고 보고하여 본 실험의 결 과와 유사한 경향을 보였다.

Table 2. Density and $\mathrm{pH}$ of rice cookies dough added with Lentinus edodes powder

\begin{tabular}{ccccc}
\hline \multirow{2}{*}{ Composition } & \multicolumn{4}{c}{ Group $^{1)}$} \\
\cline { 2 - 5 } & $\mathrm{C}-0$ & $\mathrm{C}-4$ & $\mathrm{C}-8$ & $\mathrm{C}-12$ \\
\hline Density $(\mathrm{g} / \mathrm{mL})$ & $1.11 \pm 0.00^{2) 33)}$ & $1.13 \pm 0.00^{\mathrm{ab}}$ & $1.14 \pm 0.02^{\mathrm{b}}$ & $1.16 \pm 0.03^{\mathrm{c}}$ \\
$\mathrm{pH}$ & $6.55 \pm 0.03^{\mathrm{c}}$ & $6.34 \pm 0.03^{\mathrm{b}}$ & $6.18 \pm 0.01^{\mathrm{a}}$ & $6.16 \pm 0.16^{\mathrm{a}}$ \\
\hline
\end{tabular}

${ }^{1)} \mathrm{C}-0$, Lentinus edodes powder-0\%; C-4, Lentinus edodes powder-4\%; C-8, Lentinus edodes powder-8\%; C-12, Lentinus edodes powder- $12 \%$.

${ }^{2)}$ Each value is mean $\pm \mathrm{SD}$.

${ }^{3}$ Means with different letters within a row are significantly different from each other at $p<0.05$ as determined by Duncan's multiple range test.

\section{쌀 쿠키의 퍼짐성, 손실률 및 팽창률}

표고버섯 분말 첨가 쌀 쿠키의 퍼짐성, 손실률 및 팽창률 을 측정한 결과는 Table 3 과 같다. 쿠키의 퍼짐성 지수는 대조군이 4.52 로 나타났고 $4 \%, 8 \%, 12 \%$ 첨가군은 각각 $4.66,4.35,4.34$ 로 표고버섯 분말 첨가량이 증가할수록 감소 하였는데, 이는 표고버섯의 섬유소가 쿠키의 직경이 늘어 나는 것을 방해한 것으로 사료된다. $4 \%$ 첨가군이 대조군보 다 더 높게 나타난 것은 대조군의 직경이 가장 컸으나 $4 \%$ 첨가군의 표면이 일(-)자형으로 고르게 부풀어 오른 것과 달리 대조군은 아치형( $\sim)$ 으로 부풀어 올라 가장자리보다 중심부의 두께가 높아져서 결과적으로 $4 \%$ 첨가군의 퍼짐 성이 가장 크게 측정되었기 때문이다. 쿠키의 퍼짐성 지수 는 재료들을 반죽하여 쿠키를 형성한 후 오븐에서 구워지는 동안 반죽이 바깥쪽으로 밀려 두께가 감소하고 직경이 커지 는 정도를 나타내며, 반죽의 단백질 함량, 설탕 함량, 버터 함량, 수분 함량, 반죽의 점도 등에 영향을 받으며, 특히 반죽의 수분 함량이 높은 경우 굽는 과정에서 수분 증발의 증가로 인하여 유동에 필요한 일정한 점도를 가지지 못할 때 감소하는 것으로 알려져 있다(12). 양송이버섯 분말(10)
과 새송이버섯 분말(11) 첨가 쿠키의 연구에서도 부재료의 첨가량이 증가할수록 퍼짐성이 감소하였다고 보고하여 본 실험의 결과와 유사한 경향을 보였다.

손실률은 대조군이 $13.98 \%$ 로 가장 높았고 첨가군은 7.44\%-8.23\%로 표고버섯 분말 첨가량이 증가함에 따라 감 소하였다(p<0.05). 더덕 분말 첨가 쿠키의 연구(16)에서도 더덕 분말과 반죽이 상호간 이화학적 작용에 의해 결합수를 형성하게 되어 더덕 분말 첨가량이 증가할수록 결합수의 양이 증가하여 조리과정에서 수분 손실이 감소함으로써 손실률이 감소하였다고 보고하였다.

팽창률(leavening rate)은 $4 \%$ 첨가군이 $63.38 \%, 8 \%$ 첨가 군이 $60.11 \%, 12 \%$ 첨가군이 $57.85 \%$ 로 표고버섯 분말 첨가 량이 증가함에 따라 유의적으로 감소하였다 $(\mathrm{p}<0.05)$.

Table 3. Spread factor, loss rate and leavening rate of rice cookies added with Lentinus edodes powder

\begin{tabular}{|c|c|c|c|c|}
\hline & \multicolumn{4}{|c|}{ Group $^{1)}$} \\
\hline & $\mathrm{C}-0$ & $\mathrm{C}-4$ & C-8 & $\mathrm{C}-12$ \\
\hline Spread factor & $4.52 \pm 0.09^{2 \mathrm{bb} 3)}$ & $4.66 \pm 0.06^{\mathrm{c}}$ & $4.35 \pm 0.03^{\mathrm{a}}$ & $4.34 \pm 0.03^{\mathrm{a}}$ \\
\hline Loss rate (\%) & $13.98 \pm 0.57^{\mathrm{c}}$ & $8.23 \pm 0.58^{b}$ & $7.86 \pm 0.39^{\mathrm{ab}}$ & $7.44 \pm 0.19^{\mathrm{a}}$ \\
\hline Leavening rate $(\%)$ & $100.00 \pm 0.00^{\mathrm{d}}$ & $63.38 \pm 2.48^{c}$ & $60.11 \pm 0.80^{b}$ & $57.85 \pm 0.84^{\mathrm{a}}$ \\
\hline \multicolumn{5}{|c|}{$\begin{array}{l}{ }^{1)} \mathrm{C}-0 \text {, Lentinus edodes powder }-0 \% \text {; } \mathrm{C}-4 \text {, Lentinus edodes powder- } 4 \% \text {; C-8, Lentinus } \\
\text { edodes powder- } 8 \% \text {; C- }-12 \text {, Lentinus edodes powder- }-12 \% \text {. } \\
\text { 2) Each value is mean } \mathrm{SD} \text {. } \\
\text { 3) Means with different letters within a row are significantly different from each other } \\
\text { at } p<0.05 \text { as determined by Duncan's multiple range test. }\end{array}$} \\
\hline
\end{tabular}

쌀 쿠키의 색도

표고버섯 분말 첨가 쌀 쿠키의 색도를 측정한 결과는 Table 4, Fig. 1과 같다. 밝기를 나타내는 L 값은 대조군이 82.06로 가장 높았고 첨가군은 58.39-68.69로 표고버섯 분 말 첨가량이 증가함에 따라 유의적으로 감소하였다 $(\mathrm{p}<0.05)$. 적색도를 나타내는 $\mathrm{a}$ 값은 대조군이 -1.68 로 가장 낮았으며, 첨가군이 2.16-5.75로 표고버섯 분말 첨가량이 증가함에 따라 유의적으로 증가하였는데( $\mathrm{p}<0.05)$, 이는 연 갈색을 띤 표고버섯 분말이 쿠키의 $\mathrm{L}$ 값과 $\mathrm{a}$ 값에 영향을 준 것으로 판단되며 표고버섯 분말을 첨가하여 제조한 생면 (26)과 설기떡(27), 생표고버섯 첨가 어묵(28)의 연구에서 도 부재료의 첨가량이 증가할수록 $\mathrm{L}$ 값은 감소하고 $\mathrm{a}$ 값은 증가하였다고 보고하여 본 실험의 결과와 유사한 경향을 보였다. 황색도를 나타내는 b 값은 첨가군이 28.40-28.97로 대조군(29.98)보다 낮게 나타났다. 전체적인 색도차 비교 결과 대조군과 첨가군간의 색도차가 크게 나타나서 향후 표고버섯 분말을 첨가하여 쿠키를 제조할 때 색도 차이를 고려하여야 할 것으로 판단된다.

쌀 쿠키의 경도

표고버섯 분말 첨가 쌀 쿠키의 경도를 측정한 결과는 
Table 4. Hunter's color value of rice cookies added with Lentinus edodes powder

\begin{tabular}{ccccc}
\hline & \multicolumn{4}{c}{ Group $^{1)}$} \\
\cline { 2 - 5 } & $\mathrm{C}-0$ & $\mathrm{C}-4$ & $\mathrm{C}-8$ & $\mathrm{C}-12$ \\
\hline $\mathrm{L}$ & $82.06 \pm 1.33^{2 \mathrm{~d}(3)}$ & $68.69 \pm 1.34^{\mathrm{c}}$ & $62.32 \pm 1.04^{\mathrm{b}}$ & $58.39 \pm 0.32^{\mathrm{a}}$ \\
$\mathrm{a}$ & $-1.68 \pm 0.31^{\mathrm{a}}$ & $2.16 \pm 0.12^{\mathrm{b}}$ & $4.83 \pm 0.11^{\mathrm{c}}$ & $5.75 \pm 0.27^{\mathrm{d}}$ \\
$\mathrm{b}$ & $29.98 \pm 0.07^{\mathrm{c}}$ & $28.40 \pm 0.03^{\mathrm{a}}$ & $28.97 \pm 0.03^{\mathrm{b}}$ & $28.42 \pm 0.02^{\mathrm{a}}$ \\
$\Delta \mathrm{E}^{4)}$ & 0 & 13.47 & 20.02 & 24.07 \\
\hline
\end{tabular}

${ }^{1)} \mathrm{C}-0$, Lentinus edodes powder-0\%; C-4, Lentinus edodes powder-4\%; C-8, Lentinus edodes powder- $8 \%$; C-12, Lentinus edodes powder- $12 \%$.

${ }^{2}$ Each value is mean $\pm \mathrm{SD}$.

${ }^{3)}$ Means with different letters within a row are significantly different from each other at $\mathrm{p}<0.05$ as determined by Duncan's multiple range test.

${ }^{4)} \mathrm{E}$, total color difference.
수분 증발을 용이하게 한 것으로 추측된다. 완성된 쿠키의 경도 측정 과정에서 $8 \%$ 첨가군이 다른 첨가군들보다 쉽게 부서졌기 때문에 경도가 낮게 측정되었다. $12 \%$ 첨가군의 경우 다량의 섬유소가 서로 치밀하게 결합하고 오븐에서 구워지는 동안 표면을 견고하게 하고 내부조직을 크게 덩어 리지게 하여 경도를 높인 것으로 판단된다. 양송이버섯 분 말(10)과 구아바 분말(13), 쑥부쟁이 분말(29) 첨가 쿠키의 연구에서도 부재료의 첨가량이 증가함에 따라 경도가 증가 하였다고 하여 본 실험의 결과와 유사한 경향을 보인 반면, 음나무잎 분말(6), 미역 분말(18), 타피오카 전분(20) 첨가 쿠키의 연구에서는 부재료의 첨가량이 증가할수록 경도가 감소하였다고 보고하여 본 연구와 다른 결과를 보였다. 이

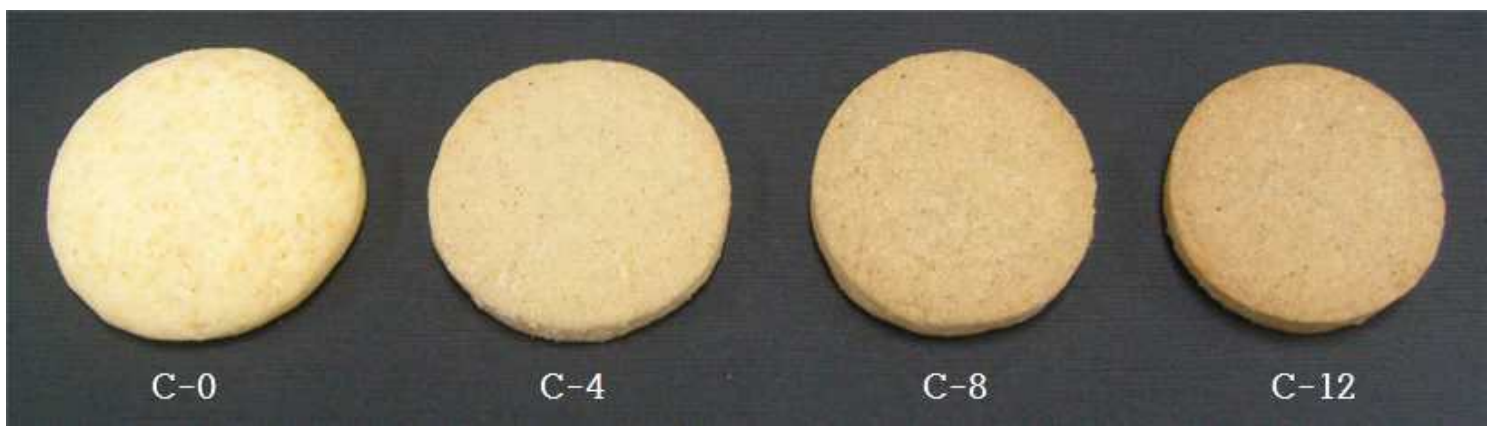

Fig. 1. External appearance of rice cookies added with Lentinus edodes powder.

C-0, Lentinus edodes powder-0\%; C-4, Lentinus edodes powder-4\%; C-8, Lentinus edodes powder-8\%; C-12, Lentinus edodes powder- $12 \%$.

Table 5와 같다. 쿠키의 경도는 대조군이 $0.95 \mathrm{~kg} / \mathrm{cm}^{2}$ 로 가장 낮았으며, $4 \%, 8 \%, 12 \%$ 첨가군은 각각 $2.15 \mathrm{~kg} / \mathrm{cm}^{2}, 1.60$ $\mathrm{kg} / \mathrm{cm}^{2}, 2.26 \mathrm{~kg} / \mathrm{cm}^{2}$ 로 첨가군이 대조군보다 높게 나타났는 데, 이는 표고버섯 분말에 함유되어 있는 섬유소가 쿠키의 경도에 영향을 준 것으로 사료된다. 일반적으로 쿠키의 수 분함 량이 높을수록 경도는 감소하는 것으로 알려져 있으나 (29) $8 \%$ 첨가군이 다른 첨가군들보다 수분 함량과 경도가 낮게 나타났다. 이는 $8 \%$ 첨가군에 함유되어 있는 적당량의 섬유소가 쿠키의 반죽 및 휴지과정에서 밀가루의 글루텐 형성을 방해하고 오븐에서 구워지는 동안 쿠키 표면과 내부 조직에 다량의 균열과 공간을 형성하여 다른 첨가군들보다

Table 5. Hardness of rice cookies added with Lentinus edodes powder

\begin{tabular}{ccccc}
\hline & \multicolumn{4}{c}{ Group $^{1)}$} \\
\cline { 2 - 5 } & $\mathrm{C}-0$ & $\mathrm{C}-4$ & $\mathrm{C}-8$ & $\mathrm{C}-12$ \\
\hline Hardness $\left(\mathrm{kg} / \mathrm{cm}^{2}\right)$ & $0.95 \pm 0.13^{2 \mathrm{a} 33)}$ & $2.15 \pm 0.35^{\mathrm{c}}$ & $1.60 \pm 0.23^{\mathrm{b}}$ & $2.26 \pm 0.32^{\mathrm{c}}$
\end{tabular}

${ }^{1)} \mathrm{C}-0$, Lentinus edodes powder- $0 \%$; C-4, Lentinus edodes powder- $4 \%$; C-8, Lentinus edodes powder- $8 \%$; C-12, Lentinus edodes powder- $12 \%$.

${ }^{2)}$ Each value is mean $\pm \mathrm{SD}$.

${ }^{3)}$ Means with different letters within a row are significantly different from each other at $p<0.05$ as determined by Duncan's multiple range test.
로써 표고버섯 분말을 $8 \%$ 첨가하여 쿠키를 제조하면 바삭 한 식감을 내는 제품 제조가 가능하리라 판단된다.

\section{쌀 쿠키의 미세구조}

표고버섯 분말 첨가 쌀 쿠키의 표면 및 내부 조직을 SEM 으로 관찰한 결과는 Fig. 2 와 같다. 표면 관찰 결과 대조군에 는 작은 기공들이 비교적 고르게 분포되어 있으나 $4 \%$ 첨가 군은 대조군보다 기공의 수가 줄어들었으며 $8 \%$ 첨가군과 $12 \%$ 첨가군에는 기공 대신 균열이 형성되어 있고, 내부 조직 관찰 결과에서 $8 \%$ 및 $12 \%$ 첨가군은 대조군과 달리 기공의 크기가 불규칙하고 덩어리로 뭉쳐져 있는 것으로 관찰되었다. 특히 $8 \%$ 첨가군의 경우 표면에는 적당한 크기 의 균열이 형성되어 있고 내부 조직은 작은 덩어리들로 구성되어 있어서 다른 첨가군들보다 수분 증발이 용이하였 을 것으로 판단된다. $12 \%$ 첨가군은 표면이 견고하고 내부 조직은 치밀하게 덩어리져 있으며 기공도 거의 형성되어 있지 않은 것으로 관찰되었다.

\section{쌀 쿠키의 수분 함량}

표고버섯 분말 첨가 쌀 쿠키의 수분 함량을 측정한 결과 는 Table 6 과 같다. 수분 함량은 대조군이 $8.32 \%, 4 \%$ 첨가군 이 $5.56 \%, 8 \%$ 첨가군이 $4.73 \%, 12 \%$ 첨가군이 $5.20 \%$ 로 첨가 

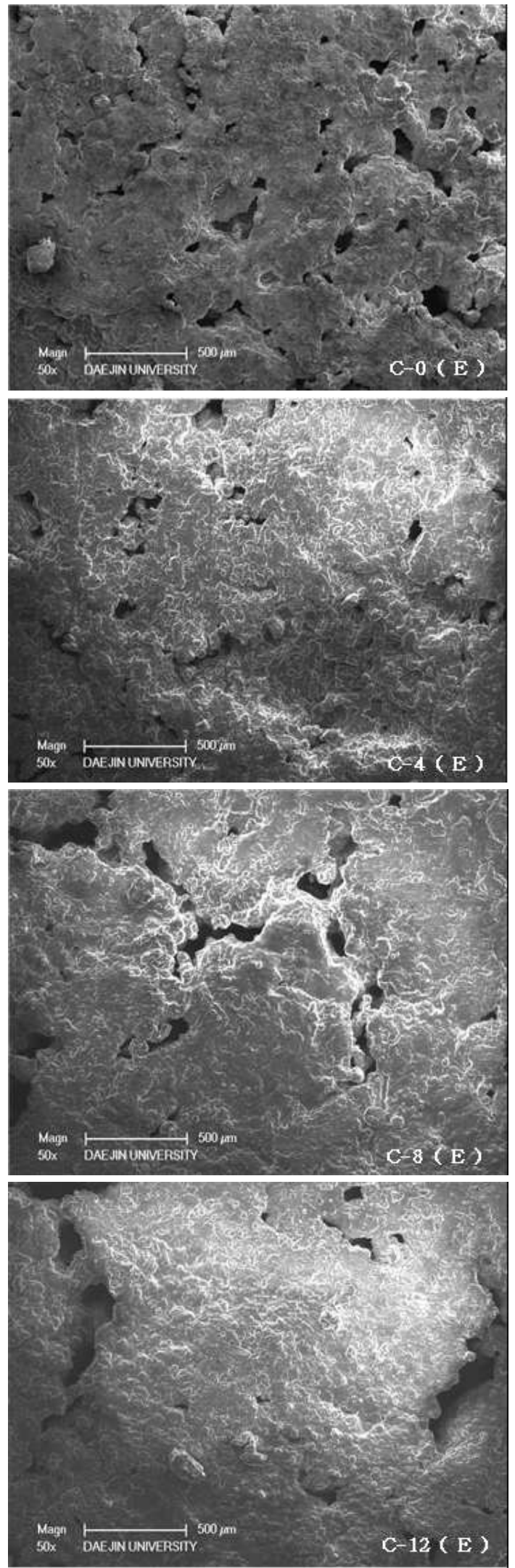
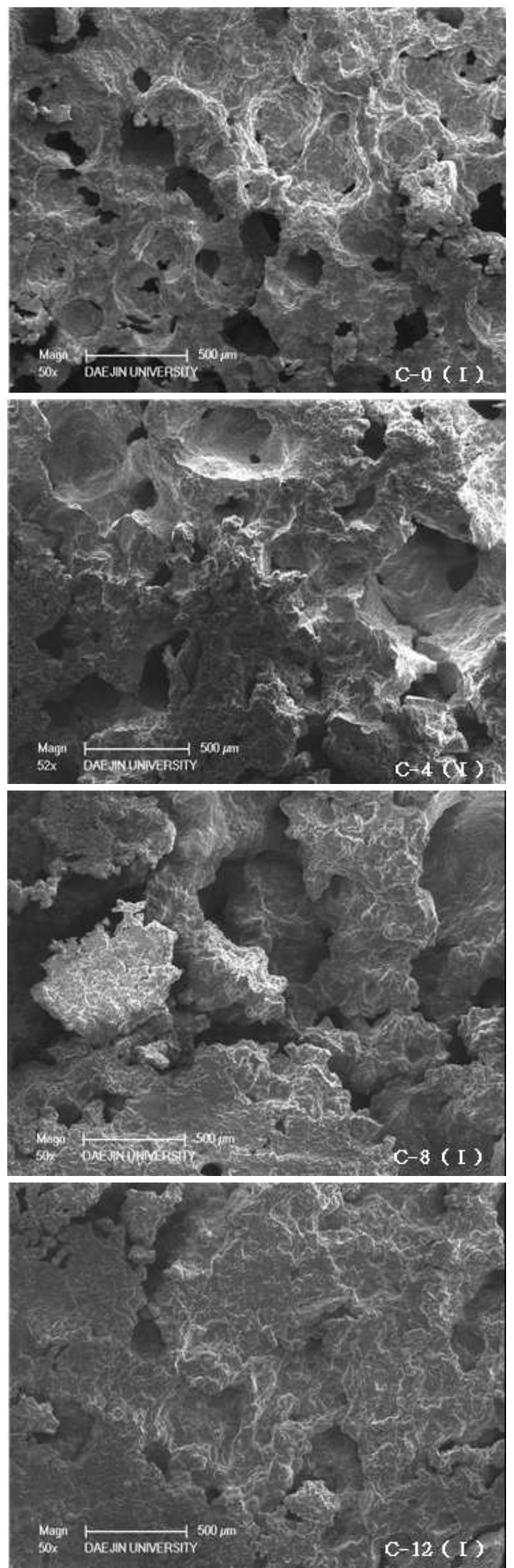

Fig. 2. Scanning electron microscope (SEM) of rice cookies added with Lentinus edodes powder.

(E), External, (I), Internal.

C-0, Lentinus edodes powder- $0 \%$; C-4, Lentinus edodes powder-4\%; C-8, Lentinus edodes powder-8\%; C-12, Lentinus edodes powder- $12 \%$. 
군이 대조군보다 낮게 나타났는데, 이는 쌀가루(수분 함량 $13.14 \%$ )와 밀가루(수분 함량 $13.18 \%$ )보다 수분 함량이 적 은 표고버섯 분말(수분 함량 $3.99 \%$ )이 쿠키의 수분 함량에 영향을 준 것으로 사료된다. $8 \%$ 첨가군이 $12 \%$ 첨가군보다 수분 함량이 낮게 나타난 이유는 $8 \%$ 첨가군의 반죽에 함유 되어 있는 섬유소가 휴지과정에서 수분을 충분히 흡수하고 밀가루 및 쌀가루의 단백질과 서로 결합한 후 오븐에서 구워지는 동안 쿠키의 표면과 내부에서 수분 증발이 용이하 도록 조직을 형성하였기 때문으로 추측된다. 반면에 $12 \%$ 첨가군의 경우 쿠키 반죽에 함유되어 있는 다량의 섬유소가 다른 재료들과 서로 결합한 후 구워지는 과정에서 쿠키의 표면을 견고하게 하고 내부 조직을 치밀하게 하여 쿠키의 수분 증발을 억제하여 $8 \%$ 첨가군보다 수분 함량이 높게 나타난 것으로 사료된다.

Table 6. Moisture content of rice cookies added with Lentinus edodes powder

\begin{tabular}{l}
\hline \multicolumn{4}{c}{ Group } \\
\cline { 2 - 5 } \\
\cline { 2 - 4 }
\end{tabular}

\section{쌀 쿠키의 기호도}

표고버섯 분말 첨가 쌀 쿠키의 기호도를 조사한 결과는 Table 7과 같다. 색은 대조군이 5.97로 높은 기호도를 보였 고 첨가군은 5.17-5.70으로 표고버섯 분말 첨가량이 증가함 에 따라 낮게 평가되었다. 냄새는 5.17-5.47의 범위로 평가 되었고 각 시료 간에 유의적인 차이를 보이지 않았다 $(\mathrm{p}<0.05)$. 맛은 대조군이 5.70으로 평가되었고 첨가군은 5.63-5.77로 평가되었으며, 전체적인 기호도는 5.37-5.90으 로 평가되어 각 시료 간 유의적인 차이가 없었다. 이로써

Table 7. Consumer acceptance test of cookies added with Lentinus edodes powder

\begin{tabular}{ccccc}
\hline & \multicolumn{4}{c}{ Group $^{1)}$} \\
\cline { 2 - 5 } & $\mathrm{C}-0$ & $\mathrm{C}-4$ & $\mathrm{C}-8$ & $\mathrm{C}-12$ \\
\hline Color & $5.97 \pm 1.13^{2 \mathrm{bb3})}$ & $5.70 \pm 0.92^{\mathrm{ab}}$ & $5.33 \pm 1.06^{\mathrm{a}}$ & $5.17 \pm 1.21^{\mathrm{a}}$ \\
Smell & $5.23 \pm 1.19$ & $5.17 \pm 1.02$ & $5.40 \pm 1.07$ & $5.47 \pm 1.14$ \\
Taste & $5.70 \pm 1.12$ & $5.63 \pm 0.89$ & $5.77 \pm 1.17$ & $5.70 \pm 1.12$ \\
Overall acceptability & $5.57 \pm 1.10$ & $5.37 \pm 0.93$ & $5.90 \pm 1.09$ & $5.70 \pm 1.12$ \\
\hline
\end{tabular}

${ }^{1)} \mathrm{C}-0$, Lentinus edodes powder-0\%; C-4, Lentinus edodes powder-4\%; C-8, Lentinus edodes powder-8\%; C-12, Lentinus edodes powder $-12 \%$.

${ }^{2)}$ Each value is mean $\pm \mathrm{SD}$.

${ }^{33}$ Means with different letters within a row are significantly different from each other at $p<0.05$ as determined by Duncan's multiple range test.
갈색을 띤 표고버섯 분말 첨가량이 증가할수록 색에 대한 기호도는 낮아졌으나, 냄새와 맛, 전체적인 기호도에서는 대조군과 유의적인 차이를 보이지 않았으므로 쿠키에 표고 버섯 분말을 $12 \%$ 첨가하는 것이 기호도가 높아 바람직할 것으로 사료된다.

\section{쌀 쿠키의 총 폴리페놀 함량 및 항산화 활성}

표고버섯 분말 첨가 쌀 쿠키의 총 폴리페놀 함량을 측정 한 결과는 Fig. 3 과 같다. 총 폴리페놀 함량은 대조군이 $9.78 \mathrm{mg} \mathrm{GAE} / 100 \mathrm{~g}$ 으로 가장 낮았고, $4 \%$ 첨가군 13.51 $\mathrm{mg} \mathrm{GAE} / 100 \mathrm{~g}, 8 \%$ 첨가군 $16.43 \mathrm{mg} \mathrm{GAE} / 100 \mathrm{~g}, 12 \%$ 첨가 군 $18.18 \mathrm{mg} \mathrm{GAE} / 100 \mathrm{~g}$ 으로 표고버섯 분말 첨가량이 증가 함에 따라 증가하였으나 $8 \%$ 첨가군과 $12 \%$ 첨가군 간에는 유의적인 차이가 없었다 $(\mathrm{p}<0.05)$. 페놀성 물질은 항산화 활 성을 나타내는 주요 물질 중 하나로(30) 식물체에 특수한 색을 부여하고 산화-환원 반응 시 기질로 작용하며, 미생물 의 공격을 막아 식물 자체를 보호하고 체내의 항산화 효소 체계와 함께 자유기로부터 조직을 보호해 주는 것으로 알려 져 있다(31). 페놀 화합물은 환원제, 수소공여제, 일중항 산소(singlet oxygen) 제거제 등의 역할을 하는 것으로 알려 져 있으며 폴리페놀 화합물이 풍부한 식품을 섭취하였을 경우 암, 심혈관질환, 면역기능장애 등 퇴행성질환의 위험 을 낮추는 것으로 보고되고 있다(32). Han 등(33)은 다양한 용매로 표고버섯 추출액을 조제하고 총 폴리페놀 함량을 측정해 본 결과 ethanol, acetone, ethyl acetate 추출물에서 각각 $2.12 \mathrm{mg} \mathrm{GAE} / \mathrm{g}, 1.81 \mathrm{mg} \mathrm{GAE} / \mathrm{g}, 1.53 \mathrm{mg} \mathrm{GAE} / \mathrm{g}$ 의 총 폴리페놀이 측정되었다고 보고하였으며, Jang 등(34)은 표고버섯 열수추물에서 $15.33 \mathrm{GAE} / \mathrm{g}$ 의 총 폴리페놀을 보 고하여 추출 용매에 따라 총 폴리페놀 함량이 다르게 나타 남을 알 수 있었다. 대조군에서 측정된 총 폴리페놀은 밀가

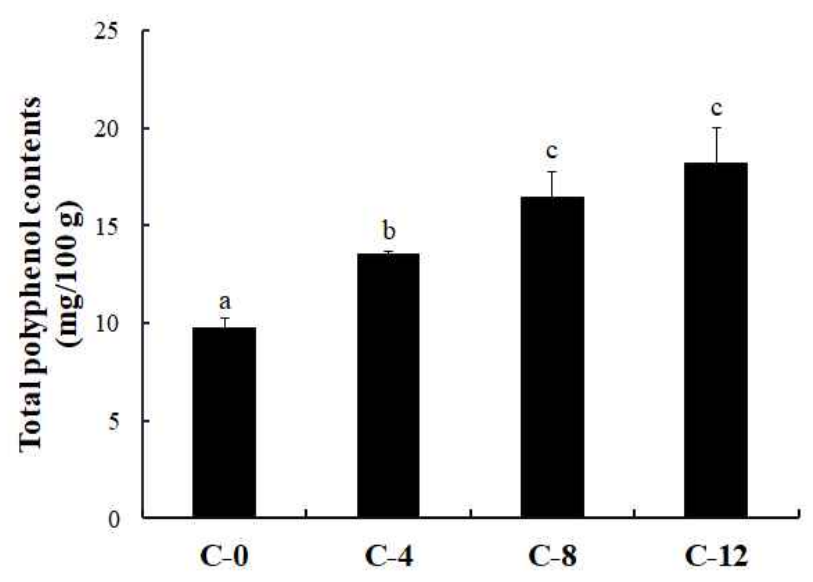

Fig. 3. Total polyphenol contents of rice cookies added with Lentinus edodes powder.

C-0, Lentinus edodes powder-0\%; C-4, Lentinus edodes powder-4\%; C-8, Lentinus edodes powder- $8 \%$; C-12, Lentinus edodes powder-12\%. Different letters above the bars indicate significantly different at $p<0.05$. 
루와 쌀가루에 의한 것으로, 쌀가루와 곰취 분말을 주재료 로 한 쿠키(35)와 밀가루와 검은비늘버섯 분말을 주재료로 한 쿠키(12)의 연구에서도 부재료가 첨가되지 않은 대조군 에서 각각 $18.53 \mathrm{mg} \mathrm{GAE} / \mathrm{g}, 67 \mathrm{mg} \%$ 의 총 폴리페놀이 측정 되었다고 보고하였다. 페놀성 화합물은 다양한 항산화 작 용을 하기 때문에 쿠키에 표고버섯 분말을 첨가하여 페놀성 화합물 함량을 증가시키는 것은 매우 바람직한 방법이라고 판단된다.

$\mathrm{DPPH}$ 는 짙은 보라색을 띠는 비교적 안전한 free radical 로서 항산화 활성을 갖는 물질로부터 전자나 수소를 제공받 으면 DPPH-H로 환원되면서 짙은 보라색이 노란색으로 탈 색되므로 다양한 식물 소재로부터 항산화능을 측정하는데 많이 이용되고 있다(36). 쌀 쿠키의 DPPH radical 소거능 측정 결과는 Fig. 4 와 같다. 대조군이 $14.66 \%$ 로 가장 낮았고, $4 \%$ 첨가군 $44.96 \%, 8 \%$ 첨가군 $77.52 \%, 12 \%$ 첨가군 $85.52 \%$ 로 표고버섯 분말 첨가량 증가에 따라 증가하였으나 $8 \%$ 첨가군과 $12 \%$ 첨가군 간에는 유의적인 차이가 없었다 $(\mathrm{p}<0.05)$.항산화능도 높아지는 것으로 나타났다. 일반적으 로 항산화능과 총 폴리페놀 함량은 정 $(+)$ 의 상관관계가 성 립한다고 보고되고 있는데(31) 양송이버섯 분말(10)과 새 송이버섯 분말(11) 첨가 쿠키의 연구에서도 부재료의 첨가 량이 증가할수록 총 폴리페놀 함량과 DPPH radical 소거능 이 증가하였다고 보고하였으며, 본 연구에서도 표고버섯 분말 첨가량이 증가함에 따라 총 폴리페놀 함량과 $\mathrm{DPPH}$ radical 소거능이 증가한 것으로 나타나서 상관관계가 있음 을 알 수 있었다.

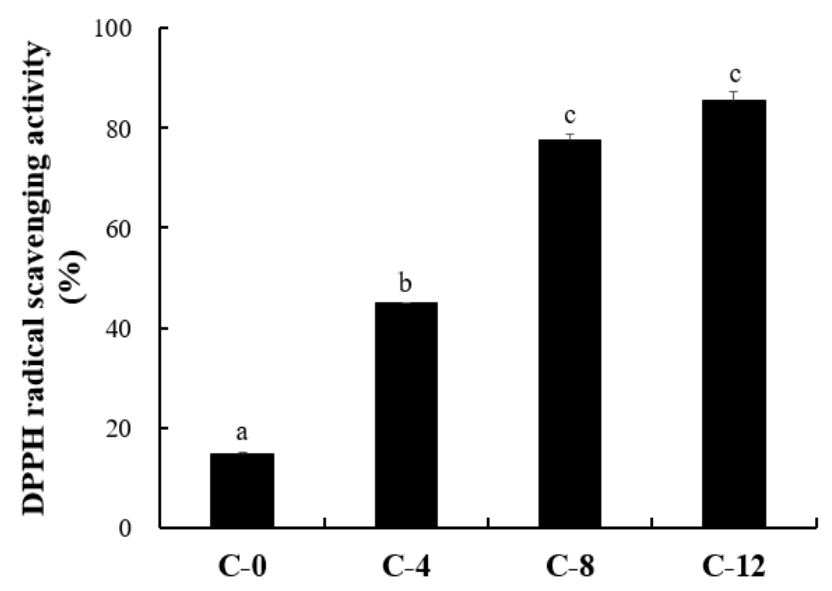

Fig. 4. DPPH radical scavenging activity of rice cookies added with Lentinus edodes powder.

C-0, Lentinus edodes powder-0\%; C-4, Lentinus edodes powder-4\%; C-8, Lentinus edodes powder-8\%; C-12, Lentinus edodes powder- $12 \%$.

Different letters above the bars indicate significantly different at $\mathrm{p}<0.05$.

환원력은 ferric ion $\left(\mathrm{Fe}^{3+}\right)$ 이 시료 중에 항산화력을 가진 물질이 존재할 경우 $\mathrm{Fe}^{2+}$ 형태로 환원되면서 녹색 또는 푸른 색을 띠는 원리를 이용하여 측정하며 환원력이 강할수록
발색 강도가 높게 나타난다(36). 환원력의 정도는 항산화 활성과 관련이 있으므로 흡광도 수치가 높게 나타날수록 높은 항산화능을 가진다. 쌀 쿠키의 환원력 측정 결과는 Fig. 5 와 같다. 대조군이 1.17 로 가장 낮았으며, 첨가군이 1.53-2.14로 표고버섯 분말 첨가량이 증가할수록 유의적으 로 증가하였다( $\mathrm{p}<0.05)$. 표고버섯 분말을 첨가하여 제조한 천연 조미료 추출물의 연구(37)에서도 버섯 첨가량이 증가 함에 따라 환원력이 증가하여 $250 \mathrm{\mu g} / \mathrm{mL}$ 에서 $0.15,500$ $\mu \mathrm{g} / \mathrm{mL}$ 에서 $0.26,750 \mu \mathrm{g} / \mathrm{mL}$ 에서 $0.31,1,000 \mu \mathrm{g} / \mathrm{mL}$ 에서 0.41 이 측정되었다고 보고하였다.

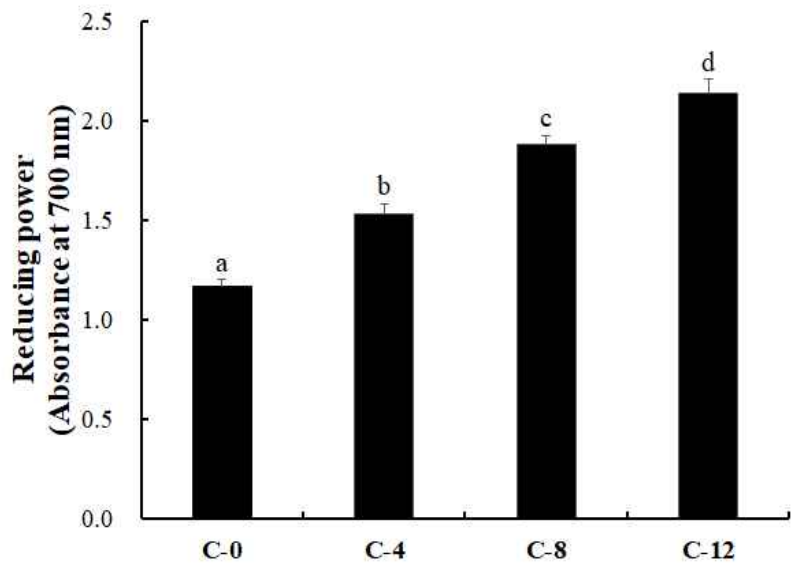

Fig. 5. Reducing power of rice cookies added with Lentinus edodes powder.

C-0, Lentinus edodes powder-0\%; C-4, Lentinus edodes powder-4\%; C-8, Lentinus edodes powder-8\%; C-12, Lentinus edodes powder- $12 \%$.

Different letters above the bars indicate significantly different at $p<0.05$

\section{요 약}

본 연구에서는 표고버섯 분말을 $4 \%, 8 \%, 12 \%$ 로 첨가하 여 쌀 쿠키를 제조하고 품질 특성, 항산화 활성 및 기호도 조사를 실시하여 기능성 쿠키를 개발하고자 하였다. 쿠키 반죽의 밀도는 표고버섯 분말 첨가량이 증가함에 따라 증가 하였고 $\mathrm{pH}$ 는 감소하였다. 쿠키의 수분 함량은 대조군이 $8.32 \%$ 로 가장 높았으며 첨가군은 4.73-5.56\%로 대조군보 다 낮았다. 표고버섯 분말 첨가량이 증가함에 따라 퍼짐성, 손실률, 팽창률 모두 감소하였다. 쿠키의 색도는 표고버섯 분말 첨가량이 증가함에 따라 $\mathrm{L}$ 값은 감소하였고 $\mathrm{a}$ 값은 증가하였으며 $\mathrm{b}$ 값은 대조군이 가장 높았다. 경도는 대조군 이 가장 낮았고 $12 \%$ 첨가군이 가장 높았다. 쿠키의 미세구 조는 표고버섯 분말 첨가량이 증가할수록 표면과 내부 조직 이 치밀해졌다. 총 폴리페놀 함량은 9.78-18.18 mg GAE/100 $\mathrm{g}$ 의 범위로 표고버섯 분말 첨가량이 증가함에 따라 증가하 였고, DPPH radical 소거능과 환원력도 증가하였다. 기호도 조사 결과, 색은 대조군이 높은 기호도를 나타내었으며 냄 
새, 맛, 전체적인 기호도는 대조군을 포함한 모든 시료들 간에 유의적인 차이가 없었다. 이러한 결과로 보아 쿠키에 표고버섯 분말을 첨가하는 것은 쿠키의 기호도를 증가시키 고 동시에 항산화 활성을 증가시킴으로써 쿠키의 가치를 높여 줄 것으로 기대되며, 쿠키 제조 시 표고버섯 분말을 $12 \%$ 첨가하는 것이 바람직할 것으로 사료된다.

\section{References}

1. Yoo YB (2016) Mushroom Sciences Crop Details. Kyohak Publishing Co, Korea, p 199-204

2. Song JY, Yoon KJ, Yoon HK, Koo SJ (2001) Effects of $\beta$-glucan from Lentinus edodes and Hordeum vulgare on blood glucose and lipid composition in alloxaninduced diabetic mice. Korean J Food Sci Technol, 33, 802-807

3. Lee JG, Kim KI, Hwang IG, Yoo SM, Min SG, Choi MJ (2015) Effects of various thermal treatments on physicochemical and nutritional properties of shiitake mushrooms. J Korean Soc Food Sci Nutr, 44, 874-881

4. Jung HW, Chung HJ (2013) Quality characteristics and amino acid content of cookies with GABA-enhanced brown rice. J Korean Soc Food Sci Nutr, 42, 1813-1820

5. Lee MH, Oh MS (2006) Quality characteristics of cookies with brown rice flour. Korean J Food Culture, 21, 685-694

6. Lee EJ, Jin SY (2015) Antioxidant activity and quality characteristics of rice cookies added Kalopanax pictus leaf powder. J East Asian Soc Dietary Life, 25, 672-680

7. Ju SM, Hong KW (2011) Quality characteristics and antioxidative effects of cookie prepared with Curcuma longa L. powder. J East Asian Soc Dietary Life, 21, 535-544

8. Kim HY, Lee IS, Kang JY, Kim GY (2002) Quality characteristics of cookies with various levels of functional rice flour. Korean J Food Sci Technol, 34, 642-646

9. Lee JS, Oh MS (2006) Quality characteristics of cookies with black rice flour. Korean J Food Cookery Sci, 22, 193-203

10. Lee JS, Jeong SS (2009) Quality characteristics of cookies prepared with button mushroom (Agaricus bisporous) powder. Korean J Food Cookery Sci, 25, 98-105

11. Kim YJ, Jung IK, Kwak EJ (2010) Quality characteristics and antioxidant activities of cookies added with Pleurotus eryngii powder. Korean J Food Sci Technol, 42, 183-189

12. Kim JW, Kim SH, Yoon HS, Song DN, Kim MJ, Chang WB, Song IG, Eom HJ (2013) Quality characteristics and antioxidant activities of cookies with Pholiota adiposa powder. J Korean Soc Food Sci Nutr, 42, 1966-1971

13. Kim SK, Choi YS (2013) The quality characteristics of rice cookies added with guava (Psidium guajava L.) powder. Korean J Culinary Res, 19, 248-258

14. Liu YN, Jeong DH, Jung JH, Kim HS (2013) Quality characteristics and antioxidant activities of cookies added with purple sweet potato powder. Korean J Food Cookery Sci, 29, 275-281

15. Choi HY (2009) Antioxidant activity and quality characteristics of pine needle cookies. J Korean Soc Food Sci Nutr, 38, 1414-1421

16. Song JH, Lee JH (2014) The quality and antioxidant properties of cookies containing Codonopsis lanceolata powder. Korean J Food Sci Technol, 46, 51-55

17. Lim JA, Lee JH (2015) Quality and antioxidant properties of cookies supplemented with black sesame powder. J Korean Soc Food Sci Nutr, 44, 1058-1063

18. Jung KJ, Lee SJ (2011) Quality characteristics of rice cookies prepared with sea mustard (Undaria pinnatifida Suringer) powder. J Korean Soc Food Sci Nutr, 40, 1453-1459

19. Hwang SH (2010) Quality characteristics of sugar snap-cookie added to carrot powder (II): Quality characteristics of sugar snap-cookie. J East Asian Soc Dietary Life, 20, 307-312

20. Lee JK, Oh SH, Lim JK (2013) Effect of tapioca starches on quality characteristics of rice cookies. Korean J Food Cookery Sci, 29, 469-478

21. AACC (2000) Approved Methods of the AACC. $10^{\text {th }}$ ed, American Association Cereal Chemists, St Paul, MN, USA, p 10-52

22. AOAC (1990) Official Methods of Analysis. $15^{\text {th }}$ ed, Association of Official Analytical Chemists, Washington DC, USA, p 31

23. Dewanto V, Wu X, Liu RH (2002) Processed sweet corn has higher antioxidant activity. J Agric Food Chem, 50, 4959-4964

24 Wong JY, Chye FY (2009) Antioxidant properties of selected tropical wild edible mushrooms. J Food Compos Anal, 22, 269-277

25. Choi YJ, Yang HS, Huh CK, Oh HH, Park TY, Kim MK, Jin SW, Seo KS, Jung HK (2013) Quality characteristics and antioxidant activity of fermented milk containing mushroom extracts. Korean J Dairy Sci Technol, 31, 187-194 
26. Kim YS (1998) Quality of wet noodle prepared with wheat flour and mushroom powder. Korean J Food Sci Technol, 30, 1373-1380

27. Cho JS, Choi MY, Chang YH (2002) Quality characteristics of Sulgiduk added with Lentinus edodes sing powder. J East Asian Soc Dietary Life, 12, 55-64

28. Son MH, Kim SY, Ha JU, Lee SC (2003) Texture properties of surimi gel containing shiitake mushroom (Lentinus edodes). J Korean Soc Food Sci Nutr, 32, 859-863

29. Lee JA (2015) Quality characteristics of cookies added with Aster yomena powder. Korean J Culinary Res, 21, 141-153

30. Jeong GT, Lee KM, Park DH (2006) Study of antimicrobial and antioxidant activities of Rumex crispus Extract. Korean Chem Eng Res, 44, 81-86

31. Kim JH, Kwon SH, Kim JK, Kim MK (2006) Effects of different mandarin formulations on antioxidative capacity and oxidative DNA damage in fifteen-month aged rats. Korean J Nutr, 39, 610-616

32. Park YO, Choi JH, Choi JJ, Yim SH, Lee HC, Yoo MJ (2011) Physicochemical characteristics of Yanggaeng with pear juice and dried pear powder added. Korean J Food Preserv, 18, 692-699

33. Han SR, Kim MJ, Oh TJ (2015) Antioxidant activities and antimicrobial effects of solvent extracts from Lentinus edodes. J Korean Soc Food Sci Nutr, 44, 1144-1149

34. Jang HL, Lee JH, Hwang MJ, Choi YM, Kim HR, Hwang JB, Nam JS (2015) Comparison of physicochemical properties and antioxidant activities between Lentinula edodes and new cultivar Lentinula edodes GNA01. J Korean Soc Food Sci Nutr, 44, 1484-1491

35. Jeong YJ , Han YS (2015) Antioxidative activities and quality characteristics of rice cookies with added Ligularia fischeri (Ledeb.) Turcz. Powder. Korean J Food Cook Sci, 31, 733-740

36. Han JM, Chung HJ (2013) Quality characteristics of Yanggaeng added with blueberry powder. Korean J Food Preserv, 20, 265-271

37. Yoo SJ, Kim SH, Won HR (2012) Component analysis and antioxidant activity of natural seasoning using shiitake (Lentinus edodes) powder. Korean J community Living Sci, 23, 245-254 